\title{
Customer Satisfaction in Imphal Urban Co-Operative Bank Ltd, Manipur
}

\author{
G. Rosybala Sharmi, Dr. L. Prabhakar
}

\begin{abstract}
Customer is the needy person who seeks genuine organisation to be trusted. Satisfying a customer is the ultimate goal and objective of the bank. Organisation sometimes does not really understand what actually in a customer's mind. On the other hand, a business organisation survives depending on its services. So, an excellence in their service is a key to achieve its long term goal. Numerous studies have emphasized the importance of customer expectations. Accordingly, this study proposes a systematically and qualitative customer expectation measurement model based on service quality tool "SERVQUAL", A 5 dimensions namely i.e., Reliability, Responsiveness, Accuracy, Tangibility, and Empathy were used to measure the satisfaction level. The study will explore the impact of customer satisfaction on the existing system and how far the customers are satisfied with the performance of the bank.
\end{abstract}

Keywords: Customer expectation, services, Imphal Urban Co-Operative Bank Ltd(IUCB).

\section{Introduction}

Today, business organizations are more customers-focused than ever before since customer satisfaction is a competitive advantage which is sustainable over the long term (Schnaars, 1991). Customer satisfaction in banking industry plays a vital role to create a healthy business status being service based industry. In any service based industry customer service is at highest priority. Customer service can be provided by well trained person in planned systematic manner or can be provided by means of well planned self-service. In banking industry customers are more directly linked with the bank's personnel for any kind of services or products. Therefore, Banks should always focus on training its employee so that they could understand each outlet and guide the customer in any matter.

\section{About The Bank}

The Imphal urban Co-operative Bank was established in $16^{\text {th }}$ June 1966 , registered under the Assam Co-operative Societies Act, 1949(Act of 1950) as extended to the then Manipur, now substituted by the Manipur Co-operative societies Act, 1976. On ${ }^{\text {st }}$ March 1967, the bank was given commencement on receipt of Licence No. ACD MN 1-P of business dated 29 $9^{\text {th }}$ November 1966 from Reserve Bank of India central office, Bombay issued under provisions of the Banking Regulation Act, 1949(As applicable to Co-operative societies).

The Bank has joint undertaking from a share capital contribution from individual members and the state. Along with this, the followings are the source of fund which helps the bank survives.

a. Deposits from the public, Government, Quasi-Government and local bodies/Organizations.

b. Borrowing from higher financing agencies.

c. Reserves and other funds created out of the Net profit from the business.

d. Income from Non-Banking Assets.

e. Fees, Grants and subsidies.

\section{Major Products And Services}

i. Deposit products

IUCB, Manipur offers different types of deposit products that cater to customer's necessity. The products has different schemes which can enjoy by all types of customers like individual, salaried, businessman, self-help groups as well as illiterate person. The bank account may be opened in the name of an individual, joint name, minor representative by a natural guardian, one of the parents name or by a guardian appointed by the court, in the name of Trust/Associative/society/club etc. subject to fulfilment of necessary conditions as per RBI Directives. More than one account cannot be opened by a person. A person can opened his saving bank account governing the rules and regulations of the bank with an initial deposit as fixed by the bank.

\section{Interest and Incidental charges:}

a. If the balance at credit of an account falls below Rs. 500/- Interest at the rate of 0.5\% p.a. will incurs a minimum balance of Rs. 500/- for a period exceeding 14 days as directed by the RBI from time to time. And no interest will incurs when the amount accured during half year is under Rs. 500/-.

b. An incidental charge of a minimum of Rs. 10/- will be made every-half year on or about $30^{\text {th }}$ September and $31^{\text {st }}$ March. 
c. Interest ceases to accure on an account of the death of the constituent.

d. A fees of Rs. 5/- will be charged at the time of closing an account, while closing, unused cheques, if any must be surrendered to the bank.

e. Interest or overdrawn accounts is calculated upon the daily balance, fraction of a Rupee to be treated as a whole Rupee.

ii. Loan products

Loans are granted only to the members who are approved by the board of securities or by the Board of Directors/Administrators. Short term loans for the period of 12 months, medium term loans for the period of 15 months to 5 years are available. Loans shall be given for productive purposes clearly defined within the economic policy of the Government. Consumptions loans may however, be given to deserving members within the limits fixed by the Board of Directors/Administrator from time to time. No member/depositor/employee can claim loans and advances as a matter of right. The decision of the Board/Administrator in disposing of loan applications shall be final and the Board/Administrator or the Bank is not bound to give the applicant any reason for the decision.

\section{iii. Miscellaneous products/services}

The bank also provide various lending schemes such as loans, cash credits and/or overdrafts or current account to members on security or securities approved by the Board of Directors/Administrators or without security. Short-term loans will be for period's unto 12 months, Medium-term loans for 15 months to 5 years and long-term loans over 5 years

\section{Aims And Objectives}

The main objective of this research work is to find out how far the customer is satisfied in regarding banking services provided by the IUCB, Manipur. Since, working staffs also plays an important role to create quality service; the research is also centred to find out the different employees motivational factors.

\section{Research Methodology}

The research studies the current level of satisfaction among the customers and employee of IUCB, Manipur. The study seeks employees' different motivational factors which has direct influence on customer satisfaction. The main problem to be dealt by the present research is the "question of performance in terms of customer satisfaction". Thus the specific problem can be explained clearly by finding the answer to these parameters as suggested by Parasuraman et al(1995). The primary data was collected through administered questionnaire which consisted of only closed ended questions. One of the limitations is the bank's policy which restricts the researcher in gathering enough data. The low number of responses from higher level staff has somehow seemed to be unbalanced survey from employee side. Hence the sample sizes were restricted to 100 respondents of which only 60 respondents data could use for study.

\section{Analysis}

This part consists of statistical analysis based on five dimensions suggested by Parasuraman et al(1995) with 24 attributes. The following table shows the respondents responses which measures its performance based on Likert scale as the highest point 5 signifies "Strongly agree" and so on and 1 signifies "Strongly disagree". $\mathrm{SA}=$ Strongly agree $\mathrm{A}=$ Agree $\mathrm{U}=$ Undecided $\mathrm{D}=$ Disagree $\mathrm{SD}=$ Strongly disagree

Table No. 1

Reliability: Reliable means the confidence of work. The work that performs by the bank what customer's expected. Customer's expectation is the customers wish to receive from the services (Nazi Nabi, 2012). Zeithaml, Bitner and Gremier (2006), suggested that customer expectations are "beliefs about a service delivery that serve as standard against which performance is done". Davidow and Uttal(1989) proposed that customer expectation is formed by many uncontrollable factors, which include previous experience with other companies, and their advertising, customers psychological condition at the time of service delivery. Miler stated that customers' expectation related to different levels of satisfaction. People choose good bank which fulfil and understand their thoughts. They need reliable information, quick and error free service which will be effective and efficient. Reliability indicates the attributes that provide services when promised.

\begin{tabular}{|c|c|c|c|c|c|c|c|c|c|c|}
\hline \multirow[t]{2}{*}{ Responses } & \multicolumn{2}{|c|}{$\begin{array}{l}\text { 1. The customer service } \\
\text { has improved since } \\
\text { computerization. }\end{array}$} & \multicolumn{2}{|c|}{$\begin{array}{l}\text { 2. Information reliability } \\
\text { has improved since } \\
\text { computerization. }\end{array}$} & \multicolumn{2}{|c|}{$\begin{array}{l}\text { 3. The existing MIS } \\
\text { is quick in customer } \\
\text { service. }\end{array}$} & \multicolumn{2}{|c|}{$\begin{array}{l}\text { 4. The existing MIS is } \\
\text { effective and efficiency. }\end{array}$} & \multicolumn{2}{|c|}{$\begin{array}{l}\text { 5. Reports generated are } \\
\text { accurate and no errors } \\
\text { occurred in service. }\end{array}$} \\
\hline & freq. & \%age & freq. & \%age & freq. & \%age & freq. & \%age & freq. & \%age \\
\hline SA & 0 & 0.0 & 0 & 0 & 10 & 16.7 & 0 & 0.0 & 0 & 0 \\
\hline A & 0 & 0.0 & 40 & 66.7 & 18 & 30.0 & 13 & 21.7 & 29 & 48.3 \\
\hline $\mathbf{U}$ & 41 & 68.0 & 20 & 33.3 & 32 & 51.6 & 35 & 58.3 & 31 & 51.7 \\
\hline D & 19 & 31.7 & 0 & 0.0 & 0 & 0.0 & 12 & 20.0 & 0 & 0.0 \\
\hline SD & 0 & 0.0 & 0 & 0.0 & 0 & 0.0 & 0 & 0.0 & 0 & 0.0 \\
\hline Total & 60 & 100.0 & 60 & 100.0 & 60 & 100.0 & 60 & 100.0 & 60 & 100.0 \\
\hline Median & 3 & & 4 & & 3 & & 3 & & 3 & \\
\hline
\end{tabular}

Source: Computed from field survey 
From the above table we found that customer agreed the statement information reliability has improved since computerization as median score is 4 whereas customer opinion regarding the other attributes are undecided as median score is 3 .

Table 1.1: Satisfaction level of Reliability regarding customers' responses

\begin{tabular}{|l|l|l|l|}
\hline Responses & Scale Assigned(a) & Frequencies(b) & Total score (a x b) \\
\hline Strongly Agree & 5 & 10 & $\mathbf{5 0}$ \\
\hline Agree & 4 & 100 & 400 \\
\hline Undecided & 3 & 159 & 477 \\
\hline Disagree & 2 & 31 & 62 \\
\hline Strongly Disagree & 1 & 0 & 0 \\
\hline Total & & 300 & 989 \\
\hline
\end{tabular}

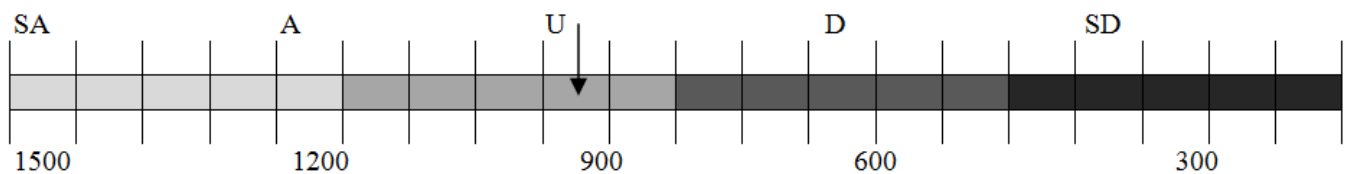

The above scale shows that the satisfaction level of customers regarding reliability lies towards the neutral.

\section{Table 2}

Empathy: Empathy encompasses to find out the solutions to the problems that faced by the customers in the banking sector. The bank staff should be trained how to tackle customers. It becomes an important for the bank staff to try to find out customer's internal thoughts. From the view of Parasuraman et al, 1988, the hidden needs of customer's could find out from the survey by asking them their needs like convenient location, suitable working hours etc.

\begin{tabular}{|c|c|c|c|c|c|c|c|c|c|c|}
\hline \multirow[t]{2}{*}{ Responses } & \multicolumn{2}{|c|}{$\begin{array}{l}\text { 1.The bank staff understand } \\
\text { the customer's need. }\end{array}$} & \multicolumn{2}{|c|}{$\begin{array}{l}2 . \text { The bank is located at } \\
\text { a convenient place. }\end{array}$} & \multicolumn{2}{|c|}{$\begin{array}{l}\text { 3. The working hour of } \\
\text { the bank is suitable for } \\
\text { us. }\end{array}$} & \multicolumn{2}{|c|}{$\begin{array}{l}\text { 4. The bank employees' } \\
\text { are helpful to us. }\end{array}$} & \multicolumn{2}{|c|}{$\begin{array}{l}\text { 5. The bank employees } \\
\text { show serious interest in } \\
\text { solving problems. }\end{array}$} \\
\hline & freq. & \%age & freq. & \%age & freq. & \%age & freq. & \%age & freq. & \%age \\
\hline SA & 0 & 0.0 & 0 & 0.0 & 0 & 0.0 & 0 & 0.0 & 0 & 0.0 \\
\hline A & 26 & 43.3 & 0 & 0.0 & 33 & 55.0 & 24 & 40.0 & 32 & 53.3 \\
\hline $\mathbf{U}$ & 24 & 40.0 & 27 & 45.0 & 27 & 45.0 & 30 & 50.0 & 28 & 46.7 \\
\hline D & 10 & 16.1 & 33 & 55.0 & 0 & 0.0 & 6 & 10.0 & 0 & 0.0 \\
\hline SD & 0 & 0.0 & 0 & 0.0 & 0 & 0.0 & 0 & 0.0 & 0 & 0.0 \\
\hline Total & 60 & 100.0 & 60 & 100.0 & 60 & 100.0 & 60 & 100.0 & 60 & 100.0 \\
\hline Median & 3 & & 2 & & 4 & & 3 & & 4 & \\
\hline
\end{tabular}

Source: Computed from field survey

It is observed from the above table that IUCB's account holders' agreed that the working hour of the bank is suitable as well as the bank employee shows serious interest in solving problems. However they neither agree nor disagree that the bank staff understand their needs, the bank employees are helpful or not. But they are not agree that the location of the bank is convenient.

Table 2.1: Satisfaction level of Empathy regarding customers' responses

\begin{tabular}{|l|l|l|l|}
\hline Responses & Scale Assigned(a) & Frequencies $(\mathbf{b})$ & Total score $(\mathbf{a}$ x b) \\
\hline Strongly Agree & $\mathbf{5}$ & $\mathbf{0}$ & $\mathbf{0}$ \\
\hline Agree & 4 & 115 & 460 \\
\hline Undecided & $\mathbf{3}$ & $\mathbf{1 3 6}$ & $\mathbf{4 0 8}$ \\
\hline Disagree & 2 & 49 & $\mathbf{9 8}$ \\
\hline Strongly Disagree & 1 & $\mathbf{0}$ & $\mathbf{0}$ \\
\hline Total & $\mathbf{3 0 0}$ & $\mathbf{9 6 6}$ \\
\hline
\end{tabular}

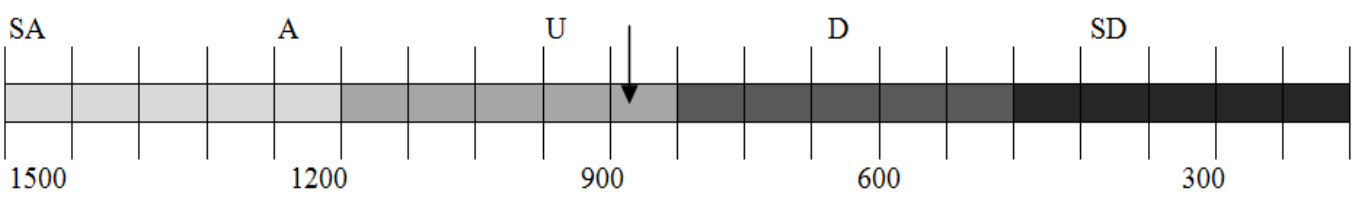

The above scale shows that the satisfaction level of customers regarding empathy lies towards the neutral.

Table 3

Responsiveness: Responsiveness is the timely reaction towards the positive response expected by customer from banking sector. When the customer requires knowing any information, the staff member should response clearly about the matter without letting them wait for long time. The transaction time taken should be less enough that there should be no longer queue. It concerns employees' attention in solving problems, full service, as well as errors correction. 


\begin{tabular}{|c|c|c|c|c|c|c|c|c|}
\hline \multirow[t]{2}{*}{ Responses } & \multicolumn{2}{|c|}{$\begin{array}{l}\text { l. The bank employee } \\
\text { support any query } \\
\text { needed by the customer. }\end{array}$} & \multicolumn{2}{|c|}{$\begin{array}{l}\text { 2. We need not to wait } \\
\text { in a long queue in the } \\
\text { bank for our purpose. }\end{array}$} & \multicolumn{2}{|c|}{$\begin{array}{l}\text { 3. If any discrepancy occurred } \\
\text { while transaction can } \\
\text { eliminate that errors quickly. }\end{array}$} & \multicolumn{2}{|c|}{$\begin{array}{l}\text { 4. The bank staff } \\
\text { response quickly the } \\
\text { customer's requirement. }\end{array}$} \\
\hline & freq. & \%age & freq. & $\%$ age & freq. & \%age & freq. & \%age \\
\hline SA & 0 & 0.0 & 0 & 0.0 & 0 & 0.0 & 0 & 0.0 \\
\hline $\mathbf{A}$ & 0 & 0.0 & 14 & 23.3 & 10 & 16.7 & 18 & 30.0 \\
\hline $\mathbf{U}$ & 38 & 63.3 & 28 & 46.7 & 32 & 53.3 & 33 & 55.0 \\
\hline D & 22 & 36.7 & 18 & 30.0 & 18 & 30.0 & 9 & 15.0 \\
\hline SD & 0 & 0.0 & 0 & 0.0 & 0 & 0.0 & 0 & 0.0 \\
\hline Total & 60 & 100.0 & 60 & 100.0 & 60 & 100.0 & 60 & 100.0 \\
\hline Median & \multicolumn{2}{|l|}{3} & \multicolumn{2}{|l|}{3} & \multicolumn{2}{|l|}{3} & \multicolumn{2}{|l|}{3} \\
\hline
\end{tabular}

Source: Computed from field survey

It is observed from the above table that they are neither agree nor disagree that the bank employee support any query needed by them, they need not wait for a long queue in the bank, any discrepancy occurred during transaction can eliminate the error quickly or not and whether the bank staff could response quickly their requirement.

Table 3.1: Satisfaction level of Responsiveness regarding customers' responses

\begin{tabular}{|l|l|l|l|}
\hline Responses & Scale Assigned(a) & Frequencies $(\mathbf{b})$ & Total score $(\mathbf{a}$ x b) \\
\hline Strongly Agree & $\mathbf{5}$ & $\mathbf{0}$ & $\mathbf{0}$ \\
\hline Agree & 4 & 42 & 168 \\
\hline Undecided & 3 & 131 & 393 \\
\hline Disagree & 2 & 67 & 134 \\
\hline Strongly Disagree & 1 & 0 & 0 \\
\hline Total & & $\mathbf{3 0 0}$ & 695 \\
\hline
\end{tabular}

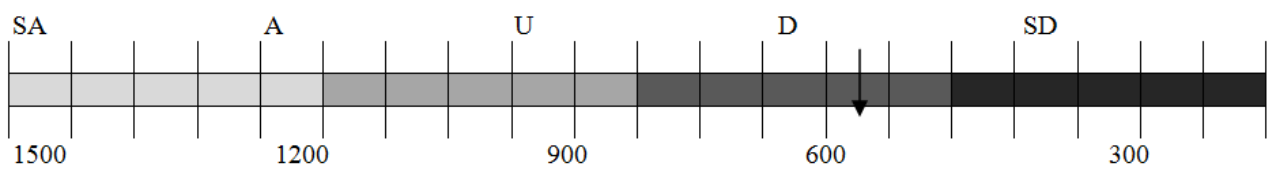

The above scale shows that the satisfaction level of customers regarding responsiveness lies towards the disagree.

Table 4

Assurance: Assurance refers the safety feeling to the bank by the customers. "It is a high risk and uncertain about the service" as they feel. The banking system should make sure the security and beliefs of the bank in any kind of transaction. There should be strict security so that it should make sure the safety of all the properties in the bank. Since it plays an important role.The parameter "Assurance" is all about the safety feeling for transaction, comparison in loan rates with other bank, Interest rates in the deposit products, and even willingness in helping to the customer.

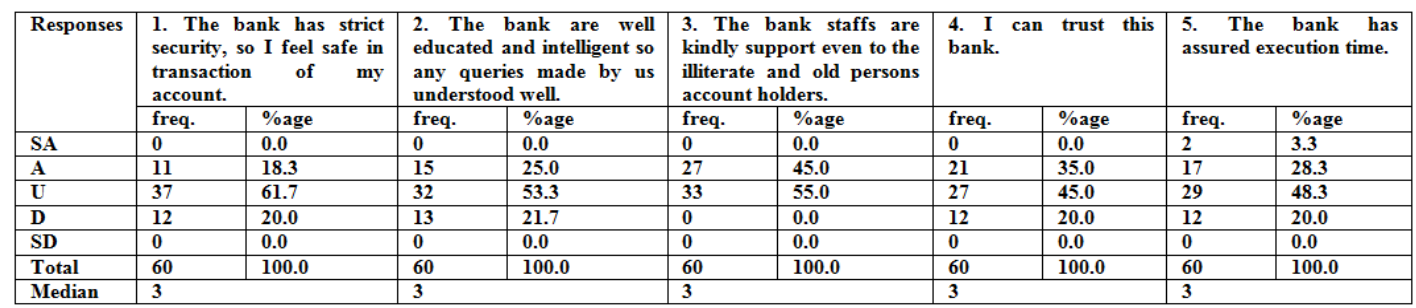

Source: Computed from field survey

Here, it is found from the above table that the account holders are neither agreed nor disagreed that the bank has strict security, all the staff are well educated, kindly support even to the illiterate and old customer, or should they trust the bank or whether the bank has assured execution time or not.

Table 4.1: Satisfaction level of Assurance regarding customers' responses

\begin{tabular}{|l|l|l|l|}
\hline Responses & Scale Assigned(a) & Frequencies $(\mathbf{b})$ & Total score (a x b) \\
\hline Strongly Agree & $\mathbf{5}$ & $\mathbf{2}$ & $\mathbf{1 0}$ \\
\hline Agree & $\mathbf{4}$ & 91 & $\mathbf{3 6 4}$ \\
\hline Undecided & $\mathbf{3}$ & $\mathbf{1 5 8}$ & $\mathbf{4 7 4}$ \\
\hline Disagree & $\mathbf{2}$ & $\mathbf{4 9}$ & $\mathbf{9 8}$ \\
\hline Strongly Disagree & $\mathbf{0}$ & $\mathbf{0}$ \\
\hline Total & & $\mathbf{3 0 0}$ & $\mathbf{9 4 6}$ \\
\hline
\end{tabular}




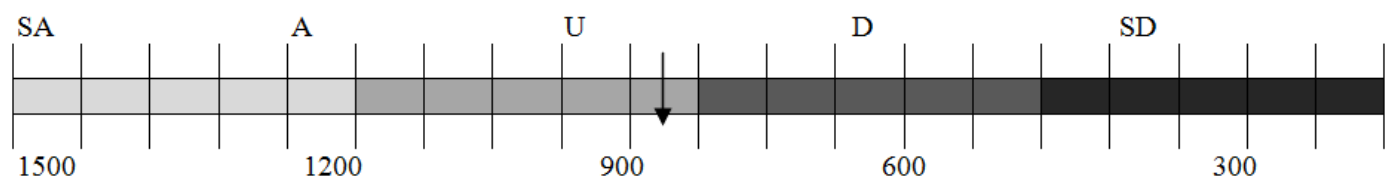

The above scale shows that the satisfaction level of customers regarding assurance lies towards the neutral.

Table No. 5

Tangibility: Tangibility signifies the appearance of the facility available in the bank like equipments, technology, advance printed material etc. These tangibles form the expectation of the customers that what the service quality will be. The parameter tangibility refers to well maintained waiting queues, clear and easy bank statement, understandable advice slip, convenient location, faster operation with modern technology.

\begin{tabular}{|c|c|c|c|c|c|c|c|c|}
\hline \multirow[t]{2}{*}{ Responses } & \multicolumn{2}{|c|}{$\begin{array}{l}\text { 1. The bank resides in a } \\
\text { convenient place. }\end{array}$} & \multicolumn{2}{|c|}{$\begin{array}{l}\text { 3. The deposit form, withdrawal } \\
\text { form, bank draft or any printed } \\
\text { material is easily understandable. }\end{array}$} & \multicolumn{2}{|c|}{$\begin{array}{l}\text { 4. The equipment used in } \\
\text { the bank is advanced } \\
\text { technology. }\end{array}$} & \multicolumn{2}{|c|}{$\begin{array}{l}\text { 5. The printed material } \\
\text { is visually appealing. }\end{array}$} \\
\hline & freq. & \%age & freq. & \%age & freq. & \%age & freq. & \%age \\
\hline $\mathrm{SA}$ & 0 & 0.0 & 0 & 0 & 0 & 0.0 & 0 & 0.0 \\
\hline A & 25 & 41.7 & 39 & 65.0 & 27 & 45.0 & 37 & 61.7 \\
\hline $\mathrm{U}$ & 35 & 58.3 & 21 & 35.0 & 24 & 40.0 & 14 & 23.3 \\
\hline $\mathrm{D}$ & 0 & 0.0 & 0 & 0.0 & 9 & 15.0 & 0 & 0.0 \\
\hline SD & 0 & 0.0 & 0 & 0.0 & 0 & 0.0 & 9 & 15.0 \\
\hline Total & 60 & 100.0 & 60 & 100.0 & 60 & 100.0 & 60 & 100.0 \\
\hline Median & 3 & & 4 & & 3 & & 4 & \\
\hline
\end{tabular}

Source: Computed from field survey

As can be observed from the above table that they agree that the deposit form, withdrawal form, bank draft or any printed material is easily understandable as well as the printed material is visually appealing. But it is found to be neutral that whether the bank resides in a convenient place or the equipment used in the bank is advance technology or not.

Table 5.1: Satisfaction level of Tangibility regarding customers' responses

\begin{tabular}{|l|l|l|l|}
\hline Responses & Scale Assigned(a) & Frequencies $(\mathbf{b})$ & Total score $(\mathbf{a}$ x b) \\
\hline Strongly Agree & $\mathbf{5}$ & $\mathbf{0}$ & $\mathbf{0}$ \\
\hline Agree & $\mathbf{4}$ & $\mathbf{1 2 8}$ & $\mathbf{5 1 2}$ \\
\hline Undecided & $\mathbf{3}$ & $\mathbf{9 4}$ & $\mathbf{2 8 2}$ \\
\hline Disagree & $\mathbf{2}$ & $\mathbf{9}$ & $\mathbf{1 8}$ \\
\hline Strongly Disagree & $\mathbf{9}$ & $\mathbf{9}$ \\
\hline Total & & $\mathbf{2 4 0}$ & $\mathbf{8 2 1}$ \\
\hline
\end{tabular}

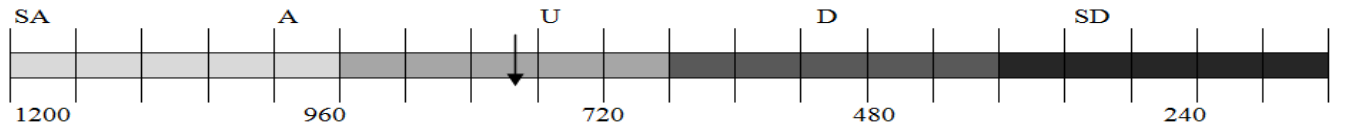

The above scale shows that the satisfaction level of customers regarding tangibility lies between the neutral and agree.

\section{Findings From The Data Collected}

i) Reliability: As observed from the analysis that account holders are found to be agreed that the existing MIS has improved after computerization. But it needs improvement in some areas like customers' service, quick processing, accuracy in reports generated and error checking.

ii)Empathy: The working hour of the bank is satisfied by the account holders as well as the bank employee shows serious interest in responding their problem. According to them, the banking system needs to decide more interestingly about the bank location. With this, the bank employee needs to be trained for customer satisfaction programme.

iii) Responsiveness: It is found from the analysis that the bank needs more improvement in responsiveness as all the attributes of this parameter are undecided.

iv) Assurance: It is observed from the analysis that this parameter also falls into neutral position. In order to improve the banking system as well as account holder attraction, the bank needs to improve all those attributes of this parameter.

v) Tangibility: Here, the IUCB's account holders satisfied that the printed materials whether it may be either for deposit form, withdrawal form, bank draft etc. But it is needed to keep an eye on the bank's location where the customers could visit conveniently, as well as used more advanced technology equipment in the bank for good purpose. 


\section{Conclusion}

An organisation is formed for mankind development. People need effective organization which fulfils their requirement in right time and right way at their best level. The results found from the above analysis are neutral according to the attributes with the IUCB's performance. The feedback from the survey is a testament to the customer expectation definitely that some attributes are much more important for the customers to judge a company. The attributes given are of critical importance for the service customers. One of the true facts is that customer can and will change them without notice or excuse. Customer value is an asset to the organization. Hence, in order to maintain the customer, the organization needs to ensure that the right products and services supported by the right promotion and making it available at the right time for customers. Establishing a professional relationship with customer empowers an organization with the knowledge of what customers need.

[1]. Dr. Manasa Naga Bhusanam "A study on Customer service quality of Banks in India” Lead Analyze Research Slutions pvt. Ltd., Bangalore

[2]. Hsieh and Yuan Design of the Customer expectation measurement model in dynamic service experience delivery, Pacific Asian Journal of the Association for Information systems vol. 2 No. 3 app 1-19, September 2010.

[3]. L.L. (1985). “A Conceptual Model of Service Quality and Its Implications for Future Research,” Journal of Marketing, Fall, 41 -50.

[4]. Nazia Nabi “Customer Expectations of Service Quality: A study on private Banks of Bangladesh.” World Review of Business Research Vol. 2. No. 4 July 2012, Pp-172-186.Parasuraman, A., Berry, L.L. and Zeithaml,

[5]. V.A. (1991). "Understanding Cus-tomer Expectations of Service," Sloan Management Review, 32(3), 39-48.

[6]. Prakash Dhakal "Customer Satisfaction Research of Nepal SBI Bank Ltd" (2012) Sureshchandar, GS, Rajendran, C \& Anantharaman, RN 2002, "Determinants of customer-perceived service quality: a confirmatory factor analysis approach", Journal of Services Marketing, 16(1), pp. 9-34.

[7]. Teas, RK 1993, “Expectations, Performance Evaluation and Consumers' Perceptions of Quality”, Journal of Marketing, 57, pp. 1834.

[8]. Zeithaml VA, Parasuraman A, \& Berry LL 1990, "Delivering quality service: Balancing customer perceptions and expectations", The Free Press, New York, NY.

[9]. Zeithaml, V, Bitner, M \& Gremler, D 2006 "Service Marketing: Integrating Customer Focus across the Firm", McGraw-Hill, New York 